\title{
Analisis Kekontinuan Fungsi pada Barisan Fungsi Konvergen
}

Wahidah Alwi

Universitas Islam Negeri Alauddin Makassar,wahidah.alwi@uin-alauddin.ac.id

Ishak R

Universitas Islam Negeri Alauddin Makassar

ABSTRAK, Penelitian ini membahas tentang tentang barisan fungsi $f_{n}$ dan hubungannya dengan fungsi kontinu $f$. Salah satu kekonvergenan dalam barisan fungsi adalah konvergen seragam, dimana jenis kekonvergenan tersebut mampu mempertahankan kekontinuan fungsi. Penelitian ini bertujuan untuk menunjukkan karakteristik barisan fungsi $f_{n}$ yang konvergen ke fungsi kontinu $f$. Kemudian akan diuraikan beberapa sifat barisan fungsi $f_{n}$ konvergen seragam serta keterkaitannya dengan fungsi kontinu $f$. Lebih jauh, dalam Penelitian ini akan ditunjukkan karakteristik barisan yang menjadi syarat cukup konvergennya barisan $f_{n}$ ke fungsi kontinu $f$.

Kata Kunci: Barisan fungsi, Fungsi kontinu, karakteristik barisan, Konvergen seragam

\section{PENDAHULUAN}

Barisan fungsi merupakan salah satu cara dalam menghampiri sebuah fungsi, sehingga kekonvergenan barisannya selalu menarik untuk dibahas. Kekonvergenan barisan fungsi terbagi menjadi dua yaitu kekonvergenan pointwise dan kekonvergenan seragam. Pengkajian yang yang lebih jauh dapat dilihat pada kekonvergenan seragam, sebab ini memiliki hubungan yang erat dengan beberapa pembahasan lain seperti kekontinuan, teori integral dan diferensial.

Pembahasan kekonvergenan seragam juga memuat criteria Cauchy. Barisan fungsi konvergen seragam dapat dicari melalui nilai mutlak dari selisih suku yang berdekatan. Sebagaimana barisan fungsi konvergen seragam, kriteria Cauchy memiliki hubungan yang erat dengan kekontinuan fungsi. Dibagian khusus, barisan fungsi monoton kontinu yang konvergen ke fungsi kontinu, mengimplikasikan bahwa barisan tersebut konvergen seragam atau lebih dikenal dengan teorema dini.
Selanjutnya, tulisan ini akan membahas karakteristik barisan fungsi yang konvergen ke fungsi kontinu atau dengan kata lain karakteristik yang menjadi syarat cukup konvergennya suatu barisan fungsi kefungsi kontinu.

Penelitian ini dibatasi pada pendefinisian fungsi kontinu pada interval $[a, b]$. Interval $[a, b]$ merupakan interval tertutup dan terbatas yang mana menurut teorema Heine-Borel interval tersebut adalah interval kompak.

\section{TINJAUANPUSTAKA}

\section{Kekontinuan}

Sebelum masuk kemateri kekontinuan, terlebih dahulu diperkenalkan materi limit. Limit merupakan pembahasan yang paling penting dalam analisis real, sebab materi selalu digunakan hampir disemua pembahasan lainnya. Limit secara intuitif dapat diartikan sebagai nilai suatu fungsi pada suatu titik. Untuk pemahaman lebih jelas dapat dilihat pada definisi berikut mining dapat dilakukan dalam beberapa langkah.

\section{Definisi 2.1}

Misalkan $A \subseteq \mathbb{R}$ dan $c$ adalah titik $\operatorname{disekitar} A$. Untuk fungsi $f: A \rightarrow \mathbb{R}$, bilangan real $L$ dikatakan sebagai limit $A$ di $c$ jika untuk setiap $\varepsilon>0$ terdapat $\delta>0$ sedemikian hingga jika $x \in$ $A$ dan $0<|x-c|<\delta$ maka berlaku

$$
|f(x)-L|<\varepsilon \text {. }
$$

Definisi tersebut merupakan definisi limit yang secara umum dituliskan sebagai $\lim _{x \rightarrow c} f(x)=$ $L$.

\section{Teorema 2.2}

Jika $f: A \rightarrow \mathbb{R}$ dan c adalah titik limit $A$. Jika $A$ memiliki limit maka limitnya tunggal.

\section{Bukti:}

Ambil $\varepsilon>0$ dan misalkan $f(x)$ memiliki limit $L$ dan $L^{\prime}$ untuk $x \rightarrow c$ maka terdapat $r_{1}>0$ dan $r_{2}>0$ sehingga untuk $x \in A$ dengan $0<$ $|x-c|<r_{1}$ berlaku 


$$
|f(x)-L|<\frac{\varepsilon}{2}
$$

Dan untuk $x \in A$ dengan $0<|x-c|<r_{2}$ berlaku

$$
\left|f(x)-L^{\prime}\right|<\frac{\varepsilon}{2}
$$

Jika diambil $r=\min \left\{r_{1}, r_{2}\right\}$ maka diperoleh

$$
\left|L-L^{\prime}\right| \leq|L-f(x)|+\left|f(x)-L^{\prime}\right|<\frac{\varepsilon}{2}+\frac{\varepsilon}{2}
$$$$
=\varepsilon
$$

Terjadi kontradiksi, sehingga limit $f(x)$ dengan $x \rightarrow c$ adalah tunggal

Selanjutnya salah satu konsep penting dalam matematika analisis yang sangat berkaitan dengan limit adalah kekontinuan. Kekontinuan suatu fungsi sangat bergantung dari ada tidaknya limit fungsi tersebut di suatu titik.

\section{Definisi 2.3}

Misalkan $A \subseteq \mathbb{R}, f: A \rightarrow \mathbb{R}$ dan $c \in A$. Fungsi $f$ dikatakan kontinu di $c$ jika untuk setiap $\varepsilon>0$ terdapat $\delta>0$ sedemikian hingga jika $x$ adalah suatu titik di $A$ terpenuhi $|x-c|<\delta$ maka berlaku

$$
|f(x)-L|<\varepsilon .
$$

definisi ini menyatakan bahwa suatu fungsi dikatakan kontinu disuatu titik jika $f$ terdefinisi dititik tersebut dan limitnya ada. Jika suatu fungsi tidak memenuhi kondisi tersebut maka dikatakan diskontinu.

Tinjauan dalam kekontinuan yang juga perlu diperhatikan adalah kekontinuan pada interval. Fungsi $f$ dikatakan kontinu pada interval jika $f$ kontinu disetiap titik pada interval tersebut atau grafik dari $f$ tidak terputus dalam interval tersebut.

\section{Definisi 2.4}

Misalkan $A \subseteq \mathbb{R}$ dan $f: A \rightarrow \mathbb{R}$. Fungsi $f$ dikatakan kontinu pada $A$ jika untuk setiap $x \in A$ dan $\varepsilon>0$ terdapat $\delta>0$ sedemikian hingga jika $u \in A$ dengan $|x-u|<\delta$ maka berlaku

$$
|f(x)-f(u)|<\varepsilon .
$$

Definisi cukup jelas memperlihatkan bahwa nilai $\delta$ bergantung pada nilai $\varepsilon$ dan $x$.

Kekontinuan memiliki ruang kajian yang cukup luas, salah satunya adalah perluasan pada kekontinuan seragam. Suatu fungsi yang kontinu seragam adalah fungsi kontinu, tetapi tidak berlaku sebaliknya. Salah satu perbedaan kekontinua dan kekontinuan seragam adalah nilai $\delta$. jika dalam kekontiuan nilai $\delta$ bergantung pada nilai $\varepsilon$ dan $x$, maka dalam kekontinuan seragam nilai $\delta$ hanya bergantung pada $\varepsilon$.

\section{Definisi 2.5}

Misalkan $A \subseteq \mathbb{R}$ dan $f: A \rightarrow \mathbb{R}$. Fungsi $f$ dikatakan kontinu seragam pada $A$ jika untuk setiap $\varepsilon>0$ terdapat $\delta>0$ sedemikian hingga jika $x, u \in A$ dengan $|x-u|<\delta$ maka berlaku

$$
|f(x)-f(u)|<\varepsilon .
$$

Selanjutnya ditunjukkan teorema yang menjamin suatu fungsi kontinu seragam.

\section{Teorema 2.6}

Misalkan $I$ interval terbatas tertutup dan $f: I \rightarrow$ $\mathbb{R}$ kontinu di $I$, maka fungsi $f$ kontinu seragam pada $I$.

\section{Bukti :}

Jika $f$ tidak kontinu seragam pada $I$, maka terdapat $\varepsilon_{0}>0$ dan dua barisan yaitu $x_{n}$ dan $y_{n}$ di $I$ sedemikian sehingga $\left|x_{n}-y_{n}\right|<\frac{1}{n}$ dan $\left|f\left(x_{n}\right)-f\left(y_{n}\right)\right| \geq \varepsilon_{0}$ untuk semua bilangan asli $n$. Karena $I$ terbatas maka $x_{n}$ juga terbatas sehingga terdaoat subbarisan $x_{n_{k}}$ dari $x_{n}$ yang konvergen ke $z$. Karena $I$ tertutup, maka $Z$ terdapat pada $I$. Cukup jeas bahwa subbarisan $y_{n_{k}}$ juga konvergen ke $z$, karena

$$
\left|y_{n_{k}}-z\right| \leq\left|y_{n_{k}}-x_{n_{k}}\right|+\left|x_{n_{k}}-z\right|
$$

Selanjutnya, jika $f$ kontinu di $z$ maka kedua barisan $f\left(x_{n_{k}}\right)$ dan $f\left(y_{n_{k}}\right)$ haruslah konvergen ke $f(z)$. Tetapi ini tidak mungkin terjadai karena $\left|f\left(x_{n}\right)-f\left(y_{n}\right)\right| \geq \varepsilon_{0}$ untuk semua bilangan asli $n$. Terjadi kontradiksi, sehingga ini membuktikan bahwa jika $f$ kontinu di $I$, maka $f$ kontinu seragam pada $I$.

Teorema ini menunjukkan bahwa fungsi kontinu yang terdefinisi pada interval tertutup dan terbatas juga kontinu seragam.

\section{Barisan}


Barisan bilangan real merupakan pemetaan dari bilangan asli kebilangan real yang diperjelas dengan definisi berikut

\section{Definisi 2.7}

Barisan bilangan real (atau barisan di R) adalah fungsi yang didefinisikan pada himpunan $N$ dengan range dalam $R$.

Selanjutnya, suatu barisan dikatakan konvergen kesuatu titik jika barisan tersebut memiliki limit.

\section{Definisi 2.8}

Barisan $X=\left(x_{n}\right)$ dikatakan konvergen ke $x \in$ $R$, atau $x$ dikatakan limit barisan $\left(x_{n}\right)$ jika untuk setiap $\varepsilon>0$ terdapat bilangan asli $K(\varepsilon)$ sedemikian hingga untuk setiap $n \geq K(\varepsilon)$, untuk $x_{n}$ berlaku $\left|x_{n}-x\right|<\varepsilon$.

Beberapa sifat barisan konvergen dapat dilihat dalam teorema berikut yang menyangkut ketunggalan nilai limit dan keterbatasan barisan.

\section{Teorema 2.9}

Jika barisan $\left(x_{n}\right)$ konvergen, maka $\left(x_{n}\right)$ limitnya tunggal.

\section{Bukti:}

Misalkan $\quad \lim _{n \rightarrow \infty}\left(x_{n}\right)=x^{\prime}$ dan $\quad \lim _{n \rightarrow \infty}\left(x_{n}\right)=x^{\prime \prime}$ dengan $x^{\prime} \neq x^{\prime \prime}$. Jika diambil $\varepsilon>0$ terdapat $K^{\prime}$ sedemikian sehingga $\left|x_{n}-x^{\prime}\right|<\frac{\varepsilon}{2}$ untuk setiap $n \geq K^{\prime \prime}$ dan terdapat $K^{\prime \prime}$ sedemikian sehingga $\left|x_{n}-x\right|<\frac{\varepsilon}{2}$ untuk semua $n \geq K^{\prime \prime}$. Dipilih $K=\max \left\{K^{\prime}, K^{\prime \prime}\right\}$. Menurut Ketaksamaan Segitiga untuk $n \geq K$ diperoleh

$$
\begin{aligned}
\left|x^{\prime}-x^{\prime \prime}\right|= & \left|\mathrm{x}^{\prime}-\mathrm{x}_{\mathrm{n}}+\mathrm{x}_{\mathrm{n}}-\mathrm{x}^{\prime \prime}\right| \\
& =\left|x^{\prime}-x_{n}\right|+\left|x_{n}-x^{\prime \prime}\right| \\
& <\frac{\varepsilon}{2}+\frac{\varepsilon}{2}=\varepsilon
\end{aligned}
$$

Karena berlaku untuk setiap $\varepsilon>0$, maka $x^{\prime}-x^{\prime \prime}=0$ yang berarti $x^{\prime}=x^{\prime \prime}$. Kontradiksi dengan pengandaian, sehingga terbukti bahwa limit $\left(x_{n}\right)$ tunggal.

\section{Teorema 2.10}

Jika $X=\left(x_{n}\right)$ konvergen, maka $X=\left(x_{n}\right)$ terbatas.

\section{Bukti:}

Diketahui $\lim \left(x_{n}\right)=x$ dan ambil $\varepsilon=1$, maka terdapat bilangan asli $K=K(1)$ sedemikian hingga berlaku $\left|x_{n}-x\right|<1$ untuk semua $n \geq K$. Dengan ketaksamaan segitiga untuk $n \geq K$ maka diperoleh

$$
\begin{gathered}
\left|x_{n}\right|=\left|x_{n}-x+x\right| \leq\left|x_{n}-x\right|+|x| \\
<1+|x|
\end{gathered}
$$

Jika dipilih

$$
M=\sup \left\{\left|x_{1}\right|,\left|x_{2}\right|, \ldots,\left|x_{k-1}\right|, 1+|x|\right\}
$$

Maka terbukti bahwa $\left|x_{n}\right| \leq M$ untuk semua $n \in$ $N$.

\section{Teorema 2.11}

(i) Jika $X=\left(x_{n}\right)$ naik (monoton) dan terbatas ke atas, maka $X=\left(x_{n}\right)$ konvergen dengan

$$
\lim \left(x_{n}\right)=\sup \left\{x_{n}: n \in N\right\} .
$$

(ii) Jika $X=\left(x_{n}\right)$ turun (monoton) dan terbatas ke bawah, maka $X=\left(x_{n}\right)$ konvergen dengan

\section{Bukti:}

$$
\lim \left(x_{n}\right)=\inf \left\{x_{n}: n \in N\right\} .
$$

Karena $X=\left(x_{n}\right)$ terbatas ke atas, maka terdapat $M \in N$ sedemikian hingga $x_{n} \leq M$ untuk semua $\in N$. Namakan $A=\left\{x_{n}: n \in N\right\}$, maka $\subset R$, terbatas ke atas dan tidak kosong. Menurut Sifat Lengkap, maka $A$ memiliki supremum, misalkan $x=\sup A$. Diambil $\varepsilon>0$, maka terdapat $K \in N$ sedemikian hingga $x-\varepsilon<x_{k} \leq x$. Karena $X$ monoton naik, maka untuk $\forall n \geq K$ berlaku

$$
x-\varepsilon<x_{k} \leq x_{n} \leq x<x+\varepsilon
$$

Atau

$$
x-\varepsilon<x_{n}<x+\varepsilon \Leftrightarrow\left|x_{n}-x\right|<\varepsilon
$$

Ini membuktikan bahwa $X=\left(x_{n}\right)$ konvergen $\operatorname{ke} x=\lim \left(x_{n}\right)=\sup \left\{x_{n}: n \in N\right\}$. pembuktian untuk infimum serupa.

\section{Barisan Fungsi}

Barisan fungsi merupakan barisan yang elemennya adalah berupa fungsi. Sehingga fungsi untuk setiap suku bergantung pada bilangan asli. Barisan fungsi konvergen terbagi atas konvergen pointwise dan konvergen seragam. Kekonvergenan pointwise didefinisikan sebagai berikut.

\section{Definisi 2.12}


Barisan fungsi $\left\{f_{n}\right\}$ dikatakan konvergen pointwise ke suatu fungsi $f$ jika $\lim _{n \rightarrow \infty} f_{n}(x)=$ $f(x)$, untuk setiap $x \in E$ dimana $E \subseteq R$.

Definisi tersebut cukup jelas menggambarkan bahwa nilai interval yang diberikan sangat mempengaruhi nilai limitnya sebagaimana dalam lemma berikut.

\section{Lemma 2.13}

Suatu barisan fungsi $\left\{f_{n}\right\}$ pada himpunan $A \subseteq R$ konvergen ke suatu fungsi jika dan hanya jika untuk setiap $\varepsilon>0$ dan setiap $x \in A$ ada bilangan asli $N_{\varepsilon, x}$ sedemikian sehingga untuk semua $n \geq N_{\varepsilon, x}$ berlaku $\left|f_{n}(x)-f(x)\right|<\varepsilon$.

\section{Bukti:}

Pertidaksamaan di atas menunjukkan bahwa $x$ berpengaruh terhadap $n$ untuk memenuhi pertidaksamaan. Sehingga jelas bahwa dalam memenuhi pertidak samaan, $n$ bergantung terhadap nilai $x$ dan $\varepsilon$.

Selanjutnya, suatu barisan yang knvergen seragam hanya bergantung pada nilai $\varepsilon$ dan berlaku untuk semua nilai $x$ dalam interval. Keknvergenan seragam didefinisikan sebagai berikut.

\section{Definisi 2.14}

Barisan fungsi $\left\{f_{n}\right\}$ bernilai riil di $E \subseteq R$. Barisan fungsi $\left\{f_{n}\right\}$ dikatakan konvergen seragam ke fungsi $f$ di $E$, jika diberikan $\varepsilon>0$, $\exists N_{\varepsilon} \exists\left|f_{n}(x)-f(x)\right|<\varepsilon, \quad \forall n \geq N_{\varepsilon}, \quad x \in E$. Fungsi $f(x)$ merupakan nilai limit dari $f_{n}(x)$ untuk nilai $n \rightarrow \infty$.

\section{Akibat 2.15}

Barisan fungsi $\left\{f_{n}\right\}$ tidak konvergen seragam ke $f$ di $E$ jika dan hanya jika $\exists \varepsilon_{0}>0 \ni$ $\nexists N$ yang memenuhi $\left|f_{n}(x)-f(x)\right|<\varepsilon_{0} \forall n \geq$ $N_{\varepsilon_{0}}, \forall x \in E$.

\section{Bukti:}

Sesuai dengan definisi bariasan konvergen seragam bahwa Barisan fungsi $\left\{f_{n}\right\}$ dikatakan konvergen seragam ke fungsi $f$ di $E$, jika diberikan $\varepsilon>0, \exists N_{\varepsilon} \ni\left|f_{n}(x)-f(x)\right|<$ $\varepsilon, \forall n \geq N_{\varepsilon}, x \in E$. Fungsi $f(x)$ merupakan nilai limit dari $f_{n}(x)$ untuk nilai $n \rightarrow \infty$, diketahui bahwa jika diambil $\varepsilon>0$ maka $\forall n \geq N_{\varepsilon}$ memenuhi pertidaksamaan $\left|f_{n}(x)-f(x)\right|<\varepsilon$. Jadi, jika diambil $\varepsilon>0$ sehingga tidak ada $n \geq$ $N_{\varepsilon}$ yang memenuhi pertidaksamaan $\mid f_{n}(x)-$ $f(x) \mid<\varepsilon$ maka $f_{n}(x)$ dinyatakan tidak konvergen seragam.

\section{METODOLOGI}

Penelitian ini merupakan kajian teori yang membahas mengenai kekontinuan dengan memperhatikan barisan fungsinya. Prosedur penelitian dimulai dengan menunjukkan hubungan konvergensi barisan fungsi dan fungsi kontinu. Kemudian menganalisis sifat barisan fungsi yang konvergen ke fungsi kontinu. Terakhir, akan ditunjukkan barisan fungsi yang konvergen ke fungsi kontinu yang berimplikasi pada ditunjukkannya karakteristik barisan fungsi yang menjadi syarat cukup kekontinuan fungsi yang didekatinya.

\section{PEMBAHASAN}

\section{Hubungan barisan fungsi konvergen dan kekontinuan}

Barisan fungsi konvergen terbagi menjadi dua yaitu konvergen pointwise dan konvergen seragam. Meskipun telah diketahui bahwa konvergen pointwise merupakan syarat perlu konvergen seragam, akan tetapi berdasarkan definisinya mengimplikasikan bahwa barisan fungsi yang konvergen pointwise tidak mampu mempertahankan kekontinuan fungsi. Lain halnya dengan kekonvergenan seragam, kekonvergenan tersebut mampu mempertahankan kekontinuan suatu fungsi . dengan kata lain barisan fungsi yang konvergen seragam akan konvergen ke suatu fungsi kontinu. Hal tersebut dapat dilihat pada teorema berikut

\section{Teorema 4.1}

Misalkan $f_{n}$ konvergen seragam ke $f$ pada suatu interval $[a, b]$. Jika $f_{n}$ kontinu di $[a, b]$ untuk tiap $n \in N$, maka $f$ juga kontinu di $[a, b]$.

\section{Bukti:}

Ambil $\varepsilon>0$ terdapat $N \in \mathbb{N}$ sedemikian hingga untuk $n \geq N$ berlaku

$$
\left|f_{n}(x)-f(x)\right|<\frac{\varepsilon}{3} \quad x \in[a, b]
$$


Misalkan $f_{N}(x)$ kontinu maka $f_{N}(x)$ juga kontinu seragam. Maka untuk setiap $\varepsilon>0$ terdapat $\delta>0$ sehingga untuk setiap $x, y \in$ $[a, b]$ dengan $|x-y|<\delta$ berlaku

$$
\left|f_{N}(x)-f_{N}(y)\right|<\frac{\varepsilon}{3}
$$

Sehingga diperoleh ketaksamaan berikut

$$
\begin{aligned}
|f(x)-f(y)| & \leq\left|f(x)-f_{N}(x)\right| \\
& +\left|f_{N}(x)-f_{N}(y)\right|+\mid f_{N}(y) \\
& -f(y) \mid \\
< & \frac{\varepsilon}{3}+\frac{\varepsilon}{3}+\frac{\varepsilon}{3} \\
=\varepsilon &
\end{aligned}
$$

Ini membuktikan bahwa $f$ kontinu.

Pernyataan ini cukup jelas menunjukkan bahwa kekonvergenan seragam hanya mampu mempertahankan kekontinuan fungsi. Dengankata lain, jika $f_{n}$ tidak kontinu maka kekonvergenan seragam tidak mampu mengakibatkan $f_{n}$ konvergen kefungsi kontinu. Oleh sebab itu, dibagian selanjutnya $f_{n}$ akan dianggap fungsi kontinu pada interval kompak $[a, b]$ yang mengimplikasikan bahwa $f_{n}$ juga konvergen seragam. Sebab konvergen seragam mengimplikasikan konvergen ke fungsi kontinu, maka selanjutnya cukup ditulis konvergen.

\section{Sifat dasar barisan fungsi yang konvergen ke fungsi kontinu}

Syarat perlu dari suatu barisan yang onvergen kefungsi kontinu adalah ketunggalan nilai limit serta keterbatasan barisannya, sebagaimana terdapat pada teorema berikut.

\section{Teorema 4.2}

Jika barisan $f_{n}$ konvergen ke $f$, maka limit barisan $f_{n}$ tunggal.

Bukti:

Andaikan $f_{n}$ konvergen ke $f$ dan $g$ dengan $f \neq g$. Maka untuk sebarang $\varepsilon>0$ terdapat $K^{\prime}$ sedemikian sehingga $\left|f_{n}-f\right|<\frac{\varepsilon}{2}$ untuk setiap $n \geq K^{\prime}$ dan terdapat $K^{\prime \prime}$ sedemikian sehingga $\left|f_{n}-g\right|<\frac{\varepsilon}{2}$ untuk setiap $n \geq K^{\prime \prime}$. Dipilih $K=\quad \max \left\{K^{\prime}, K^{\prime \prime}\right\}, \quad$ untuk $n \geq$ $K$ diperoleh

$$
\begin{aligned}
& |f-g|=\left|f-f_{\mathrm{n}}+f_{\mathrm{n}}-g\right| \\
& \quad=\left|f-f_{n}\right|+\left|f_{n}-g\right|
\end{aligned}
$$

$$
<\frac{\varepsilon}{2}+\frac{\varepsilon}{2}=\varepsilon
$$

Karena berlaku untuk setiap $\varepsilon>0$, maka $f-g=0$ yang berarti $f=g$. Kontradiksi dengan pengandaian. Jadi, terbukti bahwa limitnya tunggal.

\section{Contoh}

Tunjukkan kekonvergenan barisan $f_{n}(x)=\frac{x}{n}$ untuk $x \in[0,1]$.

$f_{n}(x)=\frac{x}{n}$ konvergen seragam menuju $f(x)=0$ pada $x \in[0,1]$ karena nilai $\left|\frac{x}{n}-0\right| \leq$ $\frac{1}{n}<\varepsilon$, yang berarti jika diambil sebarang nilai $\varepsilon>0$ ada nilai $n \geq N$ sedemikian sehingga $\left|\frac{x}{n}-0\right|<\varepsilon$ berlaku untuk semua $x \in[0,1]$.

Barisan $f_{n}$ merupakan barisan fungsi kontinu yang sebagaimana terlihat bahwa $f_{n}$ konvergen seragam ke $f=0$. Berdasarkan sifat limit barisan, cukup jelas bahwa $f$ merupakan fungsi kontinu.

Suatu himpunan tak kosong I dikatakan terbatas keatas jika terdapat $m$ sedemikian sehingga berlaku $I \leq m$. I dikatakan terbatas kebawah jika terdapat $n$ sedemikian sehingga berlaku $I \geq n$. Selanjutnya $I$ dikatakan terbatas jika $I$ terbatas keatas dan terbatas kebawah. Berikut teorema kekonvergenan yang dipengaruhi oleh keterbatasan.

\section{Teorema 4.3}

Jika barisan $f_{n}$ konvergen ke $f$, maka $f_{n}$ terbatas.

Bukti:

Diketahui $\{f n\}$ konvergen ke $f$ dan diambil $\varepsilon>0$, maka terdapat bilangan asli $K=$ $K(\varepsilon)$ sedemikian hingga berlaku $\left|f_{n}-f\right|<$ $\varepsilon$ untuk semua $n \geq K$. Jika digunkan ketaksamaan segitiga dengan $n \geq K$ maka didapat

$\left|f_{n}\right|=\left|f_{n}-f+f\right| \leq\left|f_{n}-f\right|+|f|<\varepsilon+|f|$ Jika dipilih

$$
M=\sup \left\{\left|f_{1}\right|,\left|f_{2}\right|, \ldots,\left|f_{k-1}\right|, \varepsilon+|f|\right\}
$$

Maka itu menyatakan bahwa $\left|f_{n}\right| \leq M$ untuk semua $n \in N$ 


\section{Barisan Cauchy}

Barisan Cauchy merupakan suatu kriteria yang dapat digunakan untuk menunjukkan barisan fungsi konvergen. Kriteria yang digunakan adalah dengan memperhatikan nilai mutlak dari dua suku yang berdekatan.

\section{Definisi 4.4}

Barisan $f_{n}$ dikatakan barisan Cauchy jika setiap $\varepsilon>0$ terdapat bilangan asli $N$ sehingga untuk $m, n \geq N$ berlaku $\left|f_{m}-f_{n}\right|<\varepsilon$

Salah satu sifat dasar barisan konvergen juga berlaku dalam barisan Cauchy. Sifat itu ditunjukkan dalam teorema berikut.

\section{Teorema 4.5}

Barisan Cauchy adalah barisan terbatas

\section{Bukti:}

Misalkan $f_{n}$ adalah barisan Cauchy dan diambil $\varepsilon>0$, maka terdapat bilangan asli $K=$ $K(\varepsilon)$ sedemikian hingga berlaku $\left|f_{n}-f_{k}\right|<$ $\varepsilon$ untuk semua $n \geq K$. Dengan ketaksamaan segitiga untuk $n \geq K$ maka diperoleh

Jika dipilih

$$
\begin{gathered}
\left|f_{n}\right|=\left|f_{n}-f_{k}+f_{k}\right| \leq\left|f_{n}-f_{k}\right|+\left|f_{k}\right| \\
<\varepsilon+\left|f_{k}\right|
\end{gathered}
$$

$$
M=\sup \left\{\left|f_{1}\right|,\left|f_{2}\right|, \ldots,\left|f_{k-1}\right|, \varepsilon+\left|f_{k}\right|\right\}
$$

Maka terbukti bahwa $\left|f_{n}\right| \leq M$ untuk semua $n \in$ $N$.

Selanjutnya diperlihatkan bahwa kriteria Cauchy menjamin konvergennya barisan $f_{n}$ konvergen kefungsi kontinu.

\section{Teorema 4.6}

Barisan $f_{n}$ konvergen ke $f$ jika dan hanya jika $f_{n}$ adalah barisan Cauchy.

Bukti:

Karena $f_{n}$ konvergen maka terdapat $f$ sedemikian hingga untuk setiap $\varepsilon>0$ terdapat $K \in \mathbb{N}$ sehingga untuk $n \geq K$ berlaku

$$
\left|f_{n}-f\right|<\frac{\varepsilon}{2}
$$

Berdasarkan ketaksamaan tersebut, untuk $n, m \geq K$ berlaku

$$
\begin{aligned}
\left|f_{n}-f_{m}\right| & \leq\left|f_{n}-f\right|+\left|f-f_{m}\right| \\
& <\frac{\varepsilon}{2}+\frac{\varepsilon}{2}
\end{aligned}
$$

$$
=\varepsilon
$$

Terbukti bahwa $f_{n}$ konvergen merupakan barisan Cauchy. kontinu.

Selanjutnya diperlihatkan bahwa $f$

Diketahui $f_{n}$ adalah barisan Cauchy yang berarti untuk setiap $\varepsilon>0$ terdapat $N \in \mathbb{N}$ sedemikian hingga untuk $m, n \geq N$ berlaku

$$
\left|f_{n}(x)-f_{m}(x)\right|<\varepsilon \quad x \in[a, b]
$$

Hal ini mengindikasikan bahwa barisan $f_{n}(x)$ dengan $x \in[a, b]$ merupakan baisan Cauchy di $\mathbb{R}$. Selanjutnya ini mengimplikasikan bahwa $f_{n}(x)$ konvergen yang berarti untuk setiap $\varepsilon>0$ terdapat $N \in \mathbb{N}$ sedemikian hingga untuk $n \geq N$ berlaku

$$
\left|f_{n}(x)-f(x)\right|<\frac{\varepsilon}{3} \quad x \in[a, b]
$$

Misalkan $f_{N}(x)$ kontinu, maka untuk setiap $\varepsilon>0$ terdapat $\delta>0$ sehingga untuk setiap $x, y \in[a, b]$ dengan $|x-y|<\delta$ berlaku

$$
\left|f_{N}(x)-f_{N}(y)\right|<\frac{\varepsilon}{3}
$$

Sehingga diperoleh ketaksamaan berikut

$$
\begin{aligned}
|f(x)-f(y)| & \leq\left|f(x)-f_{N}(x)\right| \\
& +\left|f_{N}(x)-f_{N}(y)\right| \\
& +\left|f_{N}(y)-f(y)\right| \\
<\frac{\varepsilon}{3}+\frac{\varepsilon}{3}+\frac{\varepsilon}{3}= & \varepsilon
\end{aligned}
$$

Jadi tebukti bahwa $f$ merupakan fungsi kontinu.

\section{Barisan (fungsi) monoton}

Barisan fungsi $f_{n}$ dikatakan monoton naik apabila $f_{n} \leq f_{n+1}$ dan $f_{n}$ monoton turun apabila $f_{n} \geq f_{n+1}$

\section{Teorema 4.7}

(1). Jika barisan $f_{n}$ naik monoton dan mempunyai supremum maka barisan $f_{n}$ konvergen ke supremumnya.

(2). Jika barisan $f_{n}$ turun monoton dan mempunyai infimum maka barisan $f_{n}$ konvergen ke infimumnya.

Bukti:

(1) Misalkan $A=\left\{f_{n}: n \in N\right\}$ dan $\quad s=$ $\sup A$. Diambil $\varepsilon>0$, maka terdapat $K \in$ $N$ sedemikian hingga $s-\varepsilon<f_{k} \leq s$. Karena $\{f n\}$ naik monoton, maka untuk $n \geq K$ berlaku 
Atau

$$
s-\varepsilon<f_{k} \leq f_{n} \leq s<s+\varepsilon
$$

$$
s-\varepsilon<f_{n}<s+\varepsilon \Leftrightarrow\left|f_{n}-s\right|<\varepsilon
$$

Jadi, terbukti bahwa $\{f n\}$ konvergen ke $s=$ $\sup \left\{f_{n}: n \in N\right\}$.

Infimum dapat dibuktikan dengan cara yang sama.

\section{Teorema 4.8}

Diberikan barisan $f_{n}(x)$ terbatas.

(1).Jika $f_{n}(x)$ naik seragam maka $f_{n}(x)$ memiliki supremum. Lebih jauh, barisan $f_{n}(x)$ konvergen ke supremumnya.

(2).Jika $f_{n}(x)$ turun seragam maka $f_{n}(x)$ memiliki infimum. Lebih jauh, barisan $f_{n}(x)$ konvergen ke infimumnya.

\section{Bukti:}

Diketahui $f_{n}$ terbatas dan naik seragam, maka untuk setiap $\varepsilon>0$ tedapat $N_{0} \in \mathbb{N}$ sehingga untuk setiap $n \geq N_{0}$ berlaku

$$
0 \leq f_{n+1}(x)-f_{n}(x)<\varepsilon \quad x \in[a, b]
$$

Cukup jelas bahwa untuk setiap $x \in$ $[a, b]$ barisan $f_{n}(x)$ terbatas di $\mathbb{R}$. Sesuai dengan sifat kelengkapan, maka terdapat $f(x)=$ $\sup f_{n}(x)$ untuk setiap $x \in[a, b]$. Berdasarkan Teorema 4.7, cukup jelas bahwa $f_{n}(x)$ konvergen ke supremumnya yaitu $f(x)$. Tapi akan dilanjutkan mengenai kekontinuan $f(x)$. Ambil $\varepsilon>0$ tedapat $N_{1} \in \mathbb{N}$ sehingga untuk setiap $n \geq N_{1}$ berlaku

$$
\left|f_{n}(x)-f(x)\right|<\frac{\varepsilon}{3}
$$

Ambil bilangan asli $N=\sup \left\{N_{0}, N_{1}\right\}$. Andaikan $f_{N}$ kontinu maka terdapat $\delta>0$ sehingga untuk setiap $x, y \in[a, b]$ dengan $\mid x-$ $y \mid<\delta$ berlaku

$$
\left|f_{N}(x)-f_{N}(y)\right|<\frac{\varepsilon}{3}
$$

Selanjutnya dapat disimpulkan bahwa untuk $x, y \in[a, b]$ dengan $|x-y|<\delta$ berlaku

$$
\begin{aligned}
& |f(x)-f(y)| \leq \mid f(x)- \\
& f_{N}(x)|+| f_{N}(x)-f_{N}(y)|+| f_{N}(y)- \\
& f(y) \mid \\
& <\frac{\varepsilon}{3}+\frac{\varepsilon}{3}+\frac{\varepsilon}{3} \\
& =\varepsilon
\end{aligned}
$$

Terbukti bahwa $f$ kontinu.
Infimum dapat dibuktikan dengan cara yang sama.

\section{Karakteristik barisan fungsi yang konvergen ke fungsi kontinu}

Pembuktian teorema konvergen seragam dan kekontinuan menunjukkan bahwa $f_{n}$ konvegen kefungsi kontinu jika dan hanya jika $f_{n}$ merupakan barisan fungsi yang kontinu di $[a, b]$. Sehingga hal pertama yang perlu diperhatikan dalam menentukan kekonvergenan barisan kefungsi kontinu adalah kekontinuan barisannya sendiri.

Sifat-sifat barisan yang telah diuraikan sebelumnya mengindikasikan suatu pernyataan bahwa barisan $f_{n}$ yang konvergen ke fungsi kontinu memiliki limit tunggal dan juga barisannya terbatas, sedangkan menurut teorema 4.3 (Teorema Cauchy) barisan $f_{n}$ akan konvergen ke fungsi kontinu $f$ jika dan hanya jika $f_{n}$ merupakan barisan Cauchy.

Sifat Barisan fungsi $f_{n}$ monoton yang merupakan kondisi spesifik dari barisan mengindikasikan bahwa $f_{n}$ yang konvergen kefungsi kontinu $f \quad$ memiliki supremum/infimum. Untuk mengetahui konvergen atau tidaknya $f_{n}$ kefungsi kontinu $f$ cukup dengan meninjau kepemilikan supremum/infimum barisannya. Menurut teorema 4.5 kemonotonan seragam mampu menjamin kepemilikan supremum/infimum barisan monoton $f_{n}$. Sehingga $f_{n}$ konvergen ke $f$ kontinu dapat diidentifikasi dengan memeriksa kemonotonan seragam dari $f_{n}$.

\section{KESIMPULAN}

Barisan yang konvergen kefungsi kontinu dipengaruhi oleh kekontinuan seragam dari barisannya, yaitu $f_{n}$ merupakan barisan fungsi kontinu. Sesuai batasan peneliatian yaitu interval terbatas dan tertutup $[a, b]$, maka $f_{n}$ kontinu juga telah kontinu seragam. Hubungan barisan konvergen dan kekontinuan juga menunjukkan bahwa konvergen seragam mampu mempertahankan kekontinuan fungsi diiterval kompak $[a, b]$, sebab barisannya akan selalu konvergen kefungsi kontinu di $[a, b]$. Selanjutnya sifat yang perlu dimiliki oleh barisan agar konvergen kefungsi kontinu adalah keterbatasan barisan. Karakteristik yang 
menjamin $f_{n}$ konvergen ke $f$ kontinu yaitu criteria Cauchy. Sehingg barisan konvergen dapat diperiksa melalui suku barisan. Untuk barisan monoton, kepemilikan supremun menjamin barisan konvergen kesupremummya. Karkteristik yang dapat dilihat agar $f_{n}$ memiliki supremum yaitu kemonotonan seragam. Criteria Cauchy dan kemonotonan seragam pada dasarnya adalah dua hal yang mirip. Sebab keduanya menggunakan selisih suku barisan. Dengan kata lain, kemotonan seragam merupakan spesifikasi kriteria Cauchy untuk barisan monoton.

\section{DAFTAR PUSTAKA}

[1] Alwi, Wahidah. (2012). "Analisis Real: Landasan Berfikir Formal dalam Matematika". Makassar: Alauddin Press

[2] Alwi, Wahidah, Muh. Irwan dan Ishak R. (2018)."Ekuivalensi Kekonvergenan Pointwise dan kekonvergenan Seragam pada Barisan fungsi". Jurnal Matematika Statistika dan Apikasinya, Vol. 6 No. 2, halaman 15-23.

[3] Bartle, R. G. (1976). "The Elements of Real Analysis $2^{\text {nd }}$. . New York. John Wiley and Sons.

[4] Bartle, R. G dan Donald R. Sherbert. (2000). "Introduction to Real Analysis $3^{\text {rd }}$. . New York. John Wiley and Sons.

[5] Goldberg, Richard R. (1976). "Method of Real Analysis".New York. John Wiley and Sons.

[6] Marsden, Jerold E. (1974). "Elementary Classiccal Analysis”. San Fransisco. W. H. Freeman and Company.

[7] Setiawan, Restu Puji dan Hartono. 2107 " Analisis Kekonvergenan pada Barisan Fungsi", Jurnal Matematika Vol 6 No 1 Tahun 2017 Universitas Negeri Yogyakarta.

[8] Trench, William F. (2013). "Introduction to Real Analysis". Trinity University.

[9] Ubaidillah, Firdaus, Soeparna Darmawijaya dan Ch. Rini Indrati. (2013). "Kekonvergenan Barisan didalam Ruang Fungsi Kontinu C $[a, b]$ '.Jurnal CAUCHY, Vol. 2 No. 4, halaman 184-188. 